\title{
Chinese Hamster Ovary Cell Adhesion to Human Platelet Thrombospondin Is Dependent on Cell Surface Heparan Sulfate Proteoglycan
}

\author{
Paul R. Kaesberg, ${ }^{*}$ William B. Ershler, ${ }^{\star \ddagger}$ Jeffrey D. Esko," and Deane F. Mosher ${ }^{\star \$}$ \\ ${ }^{*}$ Departments of Medicine, ${ }^{\S}$ Physiological Chemistry, and ${ }^{\ddagger}$ Human Oncology, University of Wisconsin, Madison, Wisconsin 53706 and \\ "Department of Biochemistry, University of Alabama, Birmingham, Alabama 35294
}

\begin{abstract}
Thrombospondin is a 420-kD platelet alpha-granule glycoprotein that binds specifically to heparin. We examined adhesion to thrombospondin of $\mathrm{CHO} \mathrm{K1}$ cells and three mutant $\mathrm{CHO}$ lines with varying deficiencies in glycosaminoglycan (GAG) synthesis. In an experiment in which the parent line (K1) had $\mathbf{7 8} \%$ adherence to thrombospondin adsorbed to tissue culture plastic, CHO S745 cells, with $<6 \%$ normal GAG synthesis had $11 \%$ adherence. CHO S677 cells, with decreased heparan sulfate proteoglycan but increased chondroitin sulfate proteoglycan, had $42 \%$ adherence. CHO S803 cells, with decreased heparan sulfate proteoglycan and normal chondroitin sulfate proteoglycan, had $31 \%$ adherence. Heparin inhibited $\mathrm{K} 1$ cell adhesion to thrombospondin, but not fibronectin, in a concentration-dependent manner. Dermatan sulfate but not chondroitin sulfate was also inhibitory. There was markedly decreased $\mathrm{K} 1$ cell adhesion to a thrombospondin core fragment that lacked the heparin binding $\mathrm{NH}_{2}$-terminal domain. Purified heparin binding domain, although poorly adhesive when adsorbed to substratum, inhibited cell adhesion to intact thrombospondin. Adhesion was better for all cell lines tested, including three human tumor cell lines, when thrombospondin was adsorbed at pH 4.0 compared with $\mathrm{pH}$ 7.4. When adsorption of thrombospondin was done at $\mathrm{pH} 7.4$, cell adhesion was better when thrombospondin was adsorbed in the presence of $\geq 0.6 \mathrm{mM}$ calcium, compared to $0.1 \mathrm{mM}$ calcium or EDTA. These findings suggest that thrombospondin can adsorb to plastic with varying degrees of exposure of a cell adhesion domain. We conclude that the thrombospondin cell adhesion receptor on $\mathrm{CHO}$ cells is a heparan sulfate proteoglycan, and that cell adhesion to thrombospondin depends on conformation of adsorbed thrombospondin.
\end{abstract}

\section{Introduction}

Thrombospondin (TSP) ${ }^{1}$ is a $420-\mathrm{kD}$ glycoprotein found in platelet alpha granules $(1,2)$. Endogenously synthesized

This work was previously published in abstract form in 1987. (Clin. Res. 36:891a.)

Address reprint requests to Dr. Mosher, University of Wisconsin, Department of Medicine, 2550 Medical Sciences Center, 1300 University Avenue, Madison, WI 53706.

Received for publication 16 October 1987 and in revised form 16 September 1988.

1. Abbreviations used in this paper: $\mathrm{ABS}$, acetate-buffered saline; $\mathrm{CHO}$, Chinese hamster ovary; GAG, glycosaminoglycan; REDV, Arg-GluAsp-Val; RGD, Arg-Gly-Asp; TBS, Tris-buffered saline; TSP, thrombospondin.

J. Clin. Invest.

(C) The American Society for Clinical Investigation, Inc. 0021-9738/89/03/0994/08 \$2.00

Volume 83, March 1989, 994-1001 thrombospondin is found in the extracellular matrix of several types of cells such as endothelial cells (3-6), aortic smooth muscle cells (6), and fibroblasts (7). A major function of platelet thrombospondin appears to be stabilization of the fibrinogen bridges between platelets formed during platelet aggregation (8-10). However, specific binding of heparin to the amino-terminal domain of thrombospondin and of type $\mathrm{V}$ collagen, laminin, fibronectin, fibrinogen, and plasminogen by the central portion of the molecule suggest other important functions $(1,2)$.

Several investigators have looked at cell adhesion to adsorbed thrombospondin, or at cell binding and metabolism of soluble thrombospondin. Roberts et al. (11) showed that G361 melanoma cells adhere and spread while C32 cells adhere but do not spread on thrombospondin adsorbed to bacteriological plastic. The heparin binding domain appeared to be involved in the spreading of G361 cells, but not to play a major role in adhesion. Varani et al. (12) reported that a squamous cell carcinoma line adheres to thrombospondin adsorbed to tissue culture plastic and that several squamous cell carcinoma lines are stimulated to attach to type I or type IV collagen by thrombospondin. Tuszynski et al. (13) have shown that B16 melanoma and fibroblasts adhere to thrombospondin dried onto glass. McKeown-Longo et al. (14) reported that fibroblasts bind and metabolize thrombospondin, and Silverstein and Nachman (15) reported that thrombospondin binds to monocytes and macrophages, and mediates platelet-monocyte adhesion, probably via a glycoprotein receptor (16). Several thrombospondin surface binding molecules have been identified. Thrombospondin binds to sulfated glycolipids on the membranes of human and sheep red blood cells (17). Asch et al. identified an $88-\mathrm{kD}$ surface glycoprotein recognized by the OKM5 antibody, and similar in properties to platelet glycoprotein IV, as the thrombospondin cell adhesion receptor on C32 melanoma cells (18). This molecule appears to be the receptor for thrombospondin-mediated platelet-monocyte adhesion (16). Heparin inhibits the binding of thrombospondin and its incorporation into the extracellular matrix by human fibroblasts (14). Heparin, platelet factor 4, fucoidan, and betathromboglobulin inhibit binding of thrombospondin by endothelial cells, whereas fibronectin, vitronectin, and fibrinogen do not (19).

Cell surface proteoglycans have properties that indicate that they may act as receptors for extracellular matrix proteins, including thrombospondin. These proteoglycans are tightly associated with the extracellular face of the plasma membrane (20). Heparan sulfate proteoglycan may be bound to cell surface proteins, and be displaceable with heparin (21), or may exist as integral membrane-bound proteoglycan (22). Binding of heparan sulfate proteoglycan (23-26) and dermatan sulfate proteoglycan (26) to fibronectin have been reported. Heparan sulfate proteoglycan also binds to laminin (27), and to collagen types I, III, and V (25, 28-30). 
To investigate the potential role of heparan sulfate proteoglycans as thrombospondin cell adhesion receptors, we examined adhesion to thrombospondin of four Chinese hamster ovary (CHO) cells that synthesize varying amounts of cell surface heparan sulfate and other glycosaminoglycans. These have been described previously (31-33). Murphy-Ullrich et al. have found that these cells have decreased ability to bind and degrade soluble thrombospondin in proportion to their decreased content of heparan sulfate (34). The present results correlate well with the failure of mutant cells to bind and degrade thrombospondin (34). Adhesion and receptor-mediated endocytosis are different in at least two respects. First, adhesion utilizes basal surface molecules while binding and degradation utilize apical surface molecules. Second, adhesion molecules are used for the placement of cells on a particular type of matrix, and for haptotaxis during such events as embryogenesis or wound healing, while binding of soluble molecules is used for hormonal control molecules, nutrients, and chemotactic factors. We also examined the ability of heparin and similar molecules to inhibit adhesion to thrombospondin of $\mathrm{CHO}$ and other cells. Finally, we investigated adhesion of $\mathrm{CHO}$ and other cells to thrombospondin that has been adsorbed at varying $\mathrm{pH}$ and calcium concentrations, to test two hypotheses: that $\mathrm{pH}$ changes cause a conformational change in thrombospondin such that a particular thrombospondin domain either to be exposed or hidden, as has been suggested for fibronectin (35), and that the change in conformation of thrombospondin caused by $\mathrm{pH}$ or calcium would effect cell adhesion.

\section{Methods}

Cell lines. The CHO parent line (K1) and mutant lines (S745, S803, and $\mathrm{S677}$ ) selected for deficiencies in glycosaminoglycan (GAG) synthesis have been described previously (31-33). S745 is deficient in xylosyltransferase, which catalyzes the first sugar transfer step in glycosaminoglycan biosynthesis. The total sulfated GAG present on the cell surface of this line is $<6 \%$ of the amount present on the wild type cell line. The $\mathrm{S} 803$ cell line has cell surface sulfated GAG that is $16 \%$ of that in the wild type cells due to a defect in glycosaminoglycan elongation, with decreased heparan sulfate but normal chondroitin sulfate proteoglycans. The $\mathbf{S} 677$ cell line has $50 \%$ of cell surface sulfated GAG with decreased heparan sulfate but increased chondroitin sulfate compared with the wild type cell line. These cells were cultured in F12 medium supplemented with $10 \%$ FCS. Human cell lines were obtained from the American Type Culture Collection (Walkersville, MD). MG-63 is a human osteosarcoma line. G361 is a human melanoma line. C32 is a human amelanotic melanoma line. These were cultured in DME with $10 \%$ FCS.

Protein purification and labeling. Human TSP was purified from the releasate of human platelets by heparin affinity and gel filtration chromatography $(9,36)$. Iodine-125 labeling was done by the chloramine- $t$ method, followed by repurification by heparin affinity chromatography (14). Unlabeled and labeled proteins were stored frozen in aliquots in Tris buffered saline (TBS, $150 \mathrm{mM}$ sodium chloride, 10 $\mathrm{mM}$ Tris chloride, $\mathrm{pH} 7.4$ ), containing $0.1 \mathrm{mM}$ calcium chloride. Fragments of thrombospondin were prepared as follows. Trypsin at 1 $\mu \mathrm{g} / \mathrm{ml}$ to was added to TSP at $200 \mu \mathrm{g} / \mathrm{ml}$ with trace ${ }^{125} \mathrm{I}$-labeled TSP in TBS containing $0.1 \mathrm{mM} \mathrm{CaCl}_{2}$. After $2 \mathrm{~min}$ at $22^{\circ} \mathrm{C}$, then adding soybean trypsin inhibitor was added at $10 \mu \mathrm{g} / \mathrm{ml}$. The fragments of thrombospondin were separated into core plus carboxy-terminal fragments and heparin binding fragments plus uncleaved thrombospondin by heparin affinity chromatography (37). Yield was determined by measuring ${ }^{125}$ I radioactivity and absorption at $280 \mathrm{~nm}$. The unbound fraction was analyzed by SDS-PAGE after reduction and found to consist predominantly of a fragment of $68 \mathrm{kD}$ and smaller fragments. The $68-\mathrm{kD}$ band is the core fragment, but the fractionation should leave the carboxy-terminal fragment in the mixture. Purified heparin binding domain was prepared by incubating TSP at $300 \mu \mathrm{g} / \mathrm{ml}$ with trypsin at $25 \mu \mathrm{g} / \mathrm{ml}$ for $30 \mathrm{~min}$. This results in nearly complete cleavage of the heparin binding domains. The heparin binding domain was purified by heparin affinity chromatography, followed by a $0.55 \mathrm{M}$ $\mathrm{NaCl}$ wash, which elutes the heparin binding domain from the heparin. Concentration was estimated by absorption at $280 \mathrm{~nm}$, since the heparin binding domain is very poorly iodinated by the chloramine $t$ method. Human fibronectin was purified from a side fraction of commercial coagulation Factor VIII production by the bromide method, as published (38).

pH and calcium dependency of thrombospondin adsorption to plates. Costar 3596 96-well tissue culture plates (Costar Data Packaging Corp., Cambridge, MA) were used. TSP was diluted to $20 \mu \mathrm{g} / \mathrm{ml}$ in acetate-buffered saline (ABS, $150 \mathrm{mM}$ sodium chloride, $10 \mathrm{mM}$ sodium acetate) adjusted to pH 4.0 or TBS adjusted to pH 7.4, each containing $10 \mathrm{mM}$ EDTA, $0.1 \mathrm{mM}$ calcium chloride, or $0.6 \mathrm{mM}$ calcium chloride. It was found to be necessary to dilute thrombospondin into $A B S$ rather than dialyze it against this buffer because of precipitation in the dialysis bag, presumably due to the insolubility of thrombospondin as it passes through its isoelectric point at $\mathrm{pH} 4.8$. Trace ${ }^{125}$ I-labeled TSP was added to unlabeled TSP, and $100 \mu \mathrm{l}$ of saline at the different pHs, containing $\sim 500,000 \mathrm{cpm}$ and $2 \mu \mathrm{g}$ of TSP was added per well. After $1 \mathrm{~h}$ of incubation at room temperature, the unbound TSP was washed off with three washings of TBS, $\mathrm{pH}$ 7.4. The third washing from each well contained $<2 \%$ of the total counts in the unadsorbed fraction. $150 \mu \mathrm{l}$ of $1 \mathrm{~N}$ sodium hydroxide was added to each well to dissolve the adsorbed protein. After a 2-h incubation, the sodium hydroxide solution was collected, and the wells were washed twice with TBS, pH 7.4, which was collected. The second wash contained $<3 \%$ of the total counts of the adsorbed fraction. The washings were counted in a Micromedix ME gamma counter (Micromedic Systems, Horsham, PA). Four replicates of each $\mathrm{pH}$ and calcium concentration were used and the mean of the results is reported.

Adhesion assay. Cells for this assay were grown to confluence in F12 (for CHO lines) or DME (for all other cell lines) plus 10\% FCS in $100 \mathrm{~mm}$ plastic petri dishes. Cells were detached with $3 \mathrm{ml} \mathrm{0.025 \%}$ trypsin, $0.025 \%$ EDTA (Gibco Laboratories, Grand Island, NY). Cells that were detached with EDTA alone were released as clumps, causing unacceptable variability of results. In control experiments, MG-63 cells that were incubated for $>30 \mathrm{~min}$ at room temperature to recover from the detachment treatment showed no difference in adhesion whether detached with trypsin-EDTA or EDTA alone (data not shown). After $3 \mathrm{~min}$ incubation of cells with trypsin-EDTA, the trypsin was inhibited with $0.5 \mathrm{ml}$ of FCS, and a single cell suspension was prepared by repeated aspiration with a pasteur pipette. The cells were washed twice in $5 . \mathrm{ml} \mathrm{DME}$ and resuspended in $5 \mathrm{ml} \mathrm{DME}$. They were counted by hemocytometer with viability determined by trypan blue exclusion. Only cell suspensions with $>90 \%$ viability were used. Cells were either used unlabeled or they were labeled for $1 \mathrm{~h}$ with $0.1 \mathrm{mCi}$ of ${ }^{51} \mathrm{Cr}$ as sodium chromate, followed by three washings in DME. After labeling, the viability was again tested and was $>90 \%$. In all experiments except those specifically designed to study recovery from trypsinization, cells had at least $60 \mathrm{~min}$ at $37^{\circ} \mathrm{C}$ to recover from trypsin treatment.

Adherence was tested on protein-coated 96-well tissue culture plates prepared in the following manner. Thrombospondin or fibronectin was diluted to $20 \mu \mathrm{g} / \mathrm{ml}$ in ABS, pH 4.0, or TBS, pH 7.4, with 10 mM EDTA, $0.1 \mathrm{mM}$ calcium chloride or $0.6 \mathrm{mM}$ calcium chloride. Inhibitor studies were done on plates coated with thrombospondin at $\mathrm{pH} 4.0$, with $0.1 \mathrm{mM}$ calcium chloride. The appropriate protein solution, $100 \mu \mathrm{l}$, was applied to the wells of the tissue culture plate, four replicates per experimental group. The plate was rinsed after $1 \mathrm{~h}$ incubation at room temperature. One set of wells was used as a control and was not incubated with thrombospondin or fibronectin. To block nonspecific protein binding sites, $100 \mu$ l of 5\% BSA (99\% pure, globulin 
free, Sigma Chemical Co., St. Louis, MO), in TBS, heat denatured at $85^{\circ} \mathrm{C}$ for $5 \mathrm{~min}$, was added to each well (including the control wells) and incubated at room temperature for $60 \mathrm{~min}$. After rinsing, 50,000 unlabeled or ${ }^{51} \mathrm{Cr}$-labeled cells were added to each well and volume brought to $0.1 \mathrm{ml}$ in each well with DME. Potential inhibitors of cell adhesion, if used, were added at this point. The plate was incubated at $37^{\circ} \mathrm{C}, 5 \% \mathrm{CO}_{2}$ and $95 \%$ humidity for $90 \mathrm{~min}$. The nonadherent cells were then removed by gentle washing of wells using a multichannel micropipette. The percentage of adherent cells that spread was determined by counting $\sim 300$ cells under an inverted microscope. Cells that were spread showed the presence of definite pseudopodia. Cells that did not spread were rounded and refractile, but were not dislodged on agitation of the plate. If unlabeled cells were used, trypsin-EDTA, $0.5 \mathrm{ml}$, was added to each well for $20 \mathrm{~min}$ to detach adherent cells. These cells were then counted in this solution by hemocytometer. Data were analyzed by computing the mean number of cells adherent and spread \pm 1 SD of four wells per experimental group. If chromium labeled cells were used, the adherent cells were dissolved with $1 \mathrm{~N}$ sodium hydroxide. The sodium hydroxide-cell lysate was collected and the radioactivity of each well counted. Data were analyzed by computing the mean counts \pm 1 SD of four wells per experimental group. This procedure was validated by comparison with results obtained by hemocytometer counting of adherent cells.

\section{Results}

Thrombospondin adsorption to plastic. The effect of $\mathrm{pH}$ and calcium concentration on thrombospondin adsorption from $20-\mu \mathrm{g} / \mathrm{ml}$ solutions to wells of plastic tissue culture plates was determined. Adsorption was found to be similar (within $30 \%$ of one another) at pH 4.0 and 7.4 in in EDTA or 0.1 or 0.6 $\mathrm{mM}$ calcium (Fig. 1). There were $\sim 1.5 \mu \mathrm{g}$ of thrombospondin

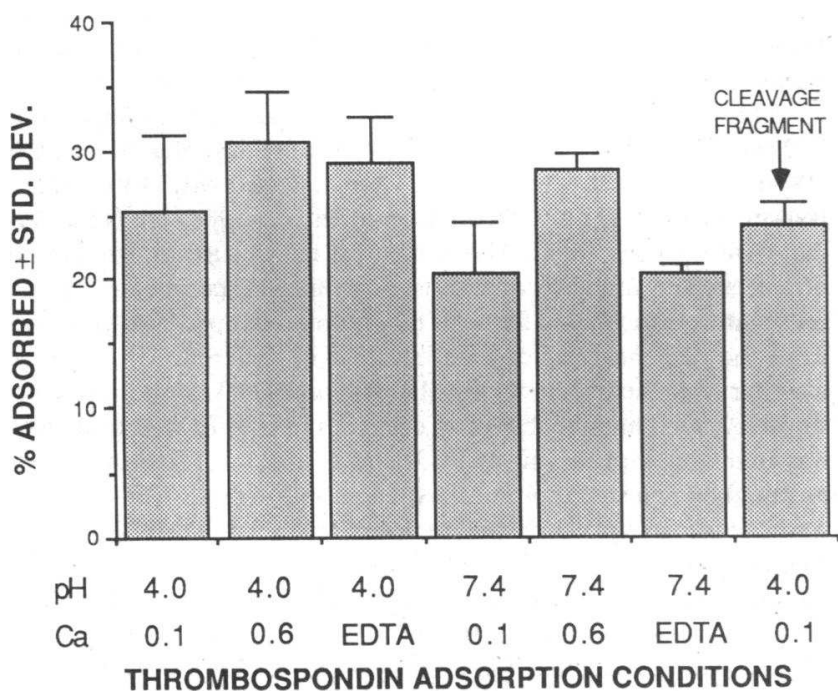

Figure 1. Thrombospondin adsorption to plastic. Thrombospondin or thrombospondin core fragment with trace ${ }^{125} \mathrm{I}$ labeled TSP or frag-

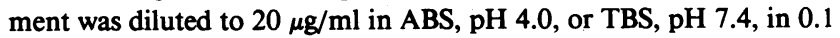
$\mathrm{mM} \mathrm{CaCl} 2,0.6 \mathrm{mM} \mathrm{CaCl}_{2}$ or $10 \mathrm{mM}$ EDTA. The fragment lacked the heparin binding domain. $100 \mu \mathrm{l}$ of each of these solutions was placed on each of four wells of a 96-well plate, incubated at room temperature for $1 \mathrm{~h}$ and then rinsed. Adsorbed thrombospondin or fragment was dissolved with $1 \mathrm{~N} \mathrm{NaOH}$ for $1 \mathrm{~h}$, and the $\mathrm{NaOH}$ was collected and counted. The third rinse of the supernatant liquid contained less than $2 \%$ of the unadsorbed counts, and the third rinse of the $\mathrm{NaOH}$ fraction contained less than $2 \%$ of the adsorbed counts. Values listed are the \% \pm standard deviation adsorbed by direct measurement. Adsorption was similar under all conditions, with intact or trypsin treated thrombospondin. adsorbed per $\mathrm{cm}^{2}$ of plastic. For comparison, Roberts et al. (11) reported that $\sim 70 \%$ of thrombospondin was adsorbed to bacteriological plastic from a solution of $3 \mu \mathrm{g} / \mathrm{ml}$, and that saturation was at $15 \mu \mathrm{g} / \mathrm{cm}^{2}$ of plastic. Similar molar amounts of thrombospondin cleavage fragment adsorbed to plastic (Fig. 1). The $\mathrm{NH}_{2}$-terminal fragment labels poorly with ${ }^{125} \mathrm{I}$, and was not tested for adsorption.

Effect of $\mathrm{pH}$ and calcium concentration at adsorption on cell adhesion to thrombospondin. The effect of $\mathrm{pH}$ of thrombospondin adsorption (in the presence of $0.1 \mathrm{mM}$ calcium) on adhesion and spreading of five cell lines is shown in Table I. Adherence for all cell lines was better on thrombospondin adsorbed at $\mathrm{pH} 4.0$ than at $\mathrm{pH}$ 7.4. With thrombospondin adsorbed at $\mathrm{pH} 4.0$, all cell lines except the CHO S745 cells adhered and all adherent lines, except CHO K1, spread. G361 melanoma showed the greatest adhesion at both the $\mathrm{pH} 4.0$ and pH 7.4 substrata. MG-63 had lower adhesion, but more adhered cells spread. C32 melanoma cells had lower adhesion and spreading than did MG-63 or G361. C32 cells did not spread on $\mathrm{pH} 7.4$ substratum, in agreement with the results of Roberts et al. (11), but they did spread on pH 4.0 substratum. There was considerable variability among experiments when conditions such as different tissue culture plates (even from the same lot), different TSP preparations and different BSA preparations were used. Results within a given experiment were consistent, however. The results shown in Table I are representative of at least three experiments with each cell type.

The effect of varying calcium concentration during thrombospondin adsorption on adhesion of $\mathrm{CHO} \mathrm{K1}$ cells is shown in Fig. 2. Enhanced adhesion was seen on substrata prepared at high calcium concentration compared to EDTA when throm-

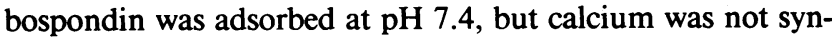
ergistic with low $\mathrm{pH}$ in enhancing adhesion on substrata prepared at $\mathrm{pH} 4.0$.

Effect of thrombospondin concentration during adsorption on subsequent $\mathrm{CHO} \mathrm{Kl}$ cell adhesion. $\mathrm{CHO}-\mathrm{K} 1$ cells were tested for adhesion on thrombospondin adsorbed at pH 4.0 and 7.4 at concentrations of $40,20,10,5$, and $2.5 \mu \mathrm{g} / \mathrm{ml}$ (Fig.

Table I. Adhesion and Spreading of Various Cell Lines to TSP

\begin{tabular}{lccccc}
\hline & \multicolumn{2}{c}{$\mathrm{pH} 4.0$} & & \multicolumn{2}{c}{$\mathrm{pH} 7.4$} \\
\cline { 2 - 3 } \cline { 5 - 6 } Cell lines: & Adhesion & Spreading & & Adhesion & Spreading \\
\hline & $\%$ & $\%$ & $\%$ & $\%$ \\
MG-63 & $66.8 \pm 11.2$ & 60.6 & & $23.6 \pm 9.2$ & 18.2 \\
G361 & $82.8 \pm 14.0$ & 26.8 & & $49.7 \pm 13.4$ & $<0.3$ \\
C32 & $43.1 \pm 8.6$ & 11.0 & $1.5 \pm 0.8$ & $<0.3$ \\
CHO K1 & $56.0 \pm 2.2$ & $<0.3$ & & $1.6 \pm 1.2$ & $<0.3$ \\
CHO S745 & $3.0 \pm 1.6$ & $<0.3$ & & $0.3 \pm 0.4$ & $<0.3$ \\
& & & &
\end{tabular}

TSP was adsorbed to plastic tissue culture plates at $20 \mu \mathrm{g} / \mathrm{ml}$ at either pH 4.0 or pH 7.4. After blocking nonspecific binding sites with BSA, a known amount of tumor cell suspension in DME was added to each well. Nonadherent cells were washed off after 90 min incubation, and the percent bound cells spread was counted under an inverted microscope. The percentage cells bound was determined by detaching bound cells with trypsin-EDTA and counting those cells. Results of adhesion are reported are the mean \pm SD of four wells per group, and results of spreading are the percentage of cells with spread morphology of 400 counted cells. 


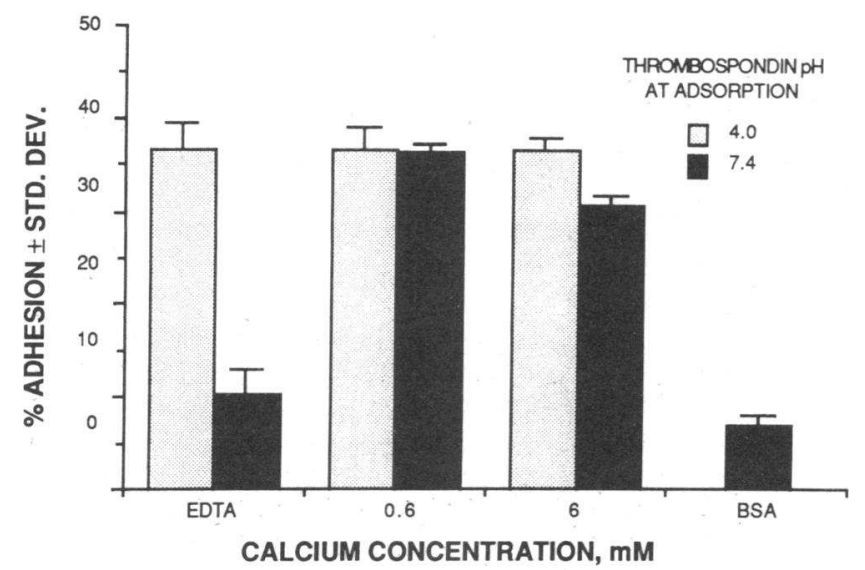

Figure 2. CHO K1 cell adhesion to thrombospondin: effects of calcium and $\mathrm{pH}$. Thrombospondin was diluted to $20 \mu \mathrm{g} / \mathrm{ml}$ in ABS, pH 4.0 , or TBS, pH 7.4 with $10 \mathrm{mM}$ EDTA, $0.6 \mathrm{mM} \mathrm{CaCl}_{2}$, or $6 \mathrm{mM}$ $\mathrm{CaCl}_{2}$. This was incubated on wells of a 96-well tissue culture plate for $1 \mathrm{~h}$, followed by $3.5 \%$ BSA. CHO K1 cells were suspended and labeled with ${ }^{51} \mathrm{Cr}$. Aliquots were placed on protein coated wells for $90 \mathrm{~min}$ at $37^{\circ} \mathrm{C}$. Unbound cells were rinsed off, and bound cells lysed with $1 \mathrm{~N} \mathrm{NaOH}$, collected, and counted. Data shown is the mean percent adhesion of four wells per experimental group \pm SD.

3). $100 \mu \mathrm{l}$ of thrombospondin at the varying concentrations in ABS, pH 4.0 or TBS, pH 7.4, was placed on each of the 0.32 $\mathrm{cm}^{2}$ wells. Adhesion was dependent on concentration of thrombospondin at both $\mathrm{pHs}$, and was greater for $\mathrm{pH} 4.0$ than $\mathrm{pH} 7.4$ at each concentration.

CHO cell mutant adhesion to thrombospondin. Fig. 4 shows adherence of $\mathrm{CHO}$ lines $\mathrm{K} 1, \mathrm{~S} 677, \mathrm{~S} 803$, and S745 to thrombospondin, which was adsorbed to $2-\mathrm{cm}^{2}$ plastic wells at $20 \mu \mathrm{g} / \mathrm{ml}$ in ABS pH 4.0 with $0.1 \mathrm{mM}$ calcium chloride. The control is adherence to wells coated with BSA only. The order

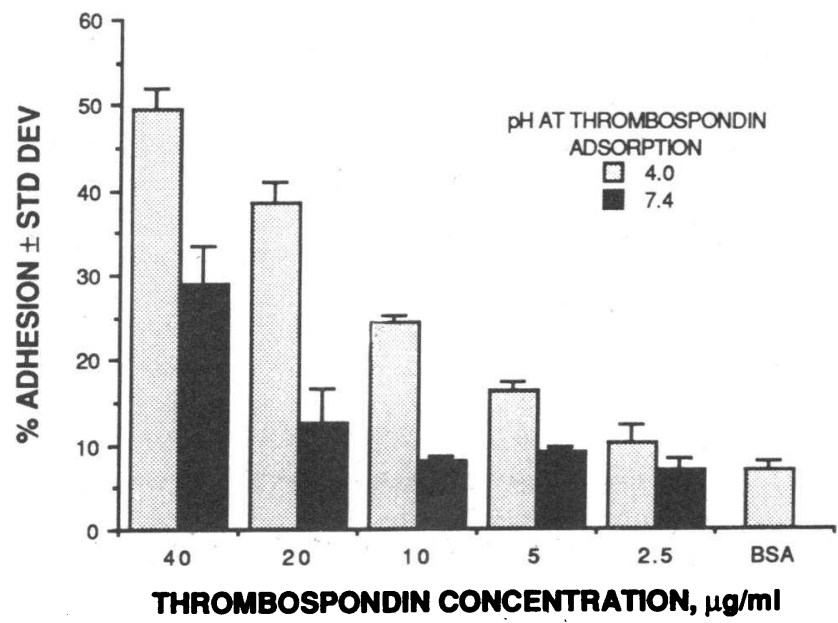

Figure 3. CHO K1 cell adhesion to TSP adsorbed at different concentrations. TSP was diluted to the labeled concentrations in ABS, $\mathrm{pH} 4.0$, or TBS with $0.1 \mathrm{mM} \mathrm{CaCl}_{2} .100-\mu 1$ aliquots were placed on wells of a 96-well tissue culture plate for $1 \mathrm{~h}$, followed by $3.5 \%$ BSA for $1 \mathrm{~h}$. CHO K1 cells were labeled with ${ }^{51} \mathrm{Cr}$ as in Fig. 2 and aliquots placed on the protein coated wells as in Fig. 2. Cells were lysed with $1 \mathrm{~N} \mathrm{NaOH}$, collected and counted. Data shown is the mean percent adhesion of four wells per experimental group \pm SD.

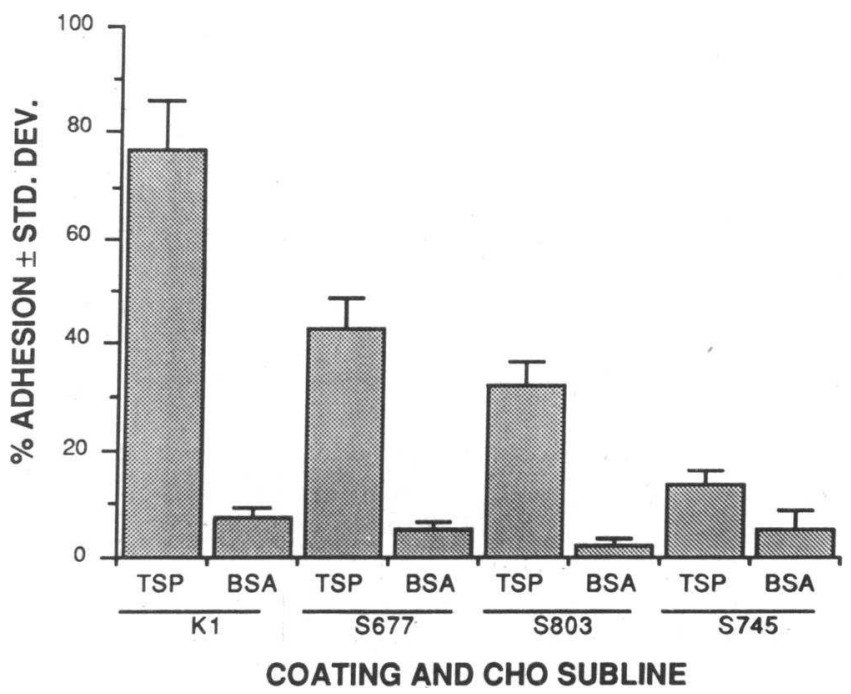

Figure 4. CHO subline adhesion to TSP. TSP-coated plates were prepared as in Fig. 2 with TSP at $20 \mu \mathrm{g} / \mathrm{ml}$ in pH 4.0 ABS. CHO K1, with normal cell surface proteoglycan, $\mathrm{CHO}$ S677, with increased chondroitin sulfate proteoglycan and decreased heparan sulfate proteoglycan, CHO S803, with normal chondroitin sulfate proteoglycan and decreased heparan sulfate proteoglycan, and CHO S745, with decreased heparan sulfate and chondroitin sulfate proteoglycans, were prepared and labeled, and placed on the protein coated wells, as in Fig. 2. Bound cells were lysed with $1 \mathrm{~N} \mathrm{NaOH}$, collected and counted. Data shown is the mean percent adhesion of four wells per experimental group $\pm \mathrm{SD}$.

of adhesion was: K1 (normal GAGs, 78\% adhesion), S677 (decreased heparan sulfate, extra chondroitin sulfate, $42 \%$ adhesion), S803 (decreased heparan sulfate, normal chondroitin sulfate, $38 \%$ adhesion), and $\mathbf{S 7 4 5}$ (decreased heparan sulfate and chondroitin sulfate, $11 \%$ adhesion). No spreading of any of the sublines was observed on thrombospondin.

Heparin inhibition of $\mathrm{CHO}$ and MG-63 cell adhesion to thrombospondin. The ability of heparin to inhibit cell adhesion to thrombospondin or fibronectin was determined. Heparin inhibited the adhesion of $\mathrm{CHO} \mathrm{K} 1$ cells to thrombospondin at low concentration. Adhesion was inhibited by $50 \%$ when heparin was added to the cell suspension at $0.2 \mu \mathrm{g} / \mathrm{ml}$ and over $75 \%$ when added at $0.6 \mu \mathrm{g} / \mathrm{ml}$ (Fig. 5). Heparin did not inhibit $\mathrm{CHO}$ $\mathrm{K} 1$ cell adhesion to fibronectin significantly up to the highest concentration tested. When heparin was added to adsorbed thrombospondin at $10 \mu \mathrm{g} / \mathrm{ml}$ then rinsed off before adding cells, adhesion of $\mathrm{CHO} \mathrm{K1}$ cells was inhibited $40 \%$ (data not shown), indicating that the heparin appears to act by binding to the thrombospondin, but that presence of heparin with cells is necessary for optimal inhibition. Incubation of $\mathrm{CHO}$ cells with heparin at $10 \mu \mathrm{g} / \mathrm{ml}$ for $2 \mathrm{~h}$ resulted in an insignificant decline in viability, measured by trypan blue exclusion, from 95 to $90 \%$. Heparin also inhibited MG-63 cell adhesion to thrombospondin, with half-maximal inhibition at $0.6 \mu \mathrm{g} / \mathrm{ml}$ (data not shown). Dermatan sulfate, at $10 \mu \mathrm{g} / \mathrm{ml}$, inhibited CHO K1 adhesion by about $50 \%$, while chondroitin sulfate at this concentration did not cause inhibition (Table II).

Effect of trypsin on adhesion to thrombospondin. CHO K1 cells were treated with $0.25 \%$ trypsin a second time after labeling with ${ }^{51} \mathrm{Cr}$. Therefore they did not have time for complete recovery posttrypsinization. They were placed on the protein- 


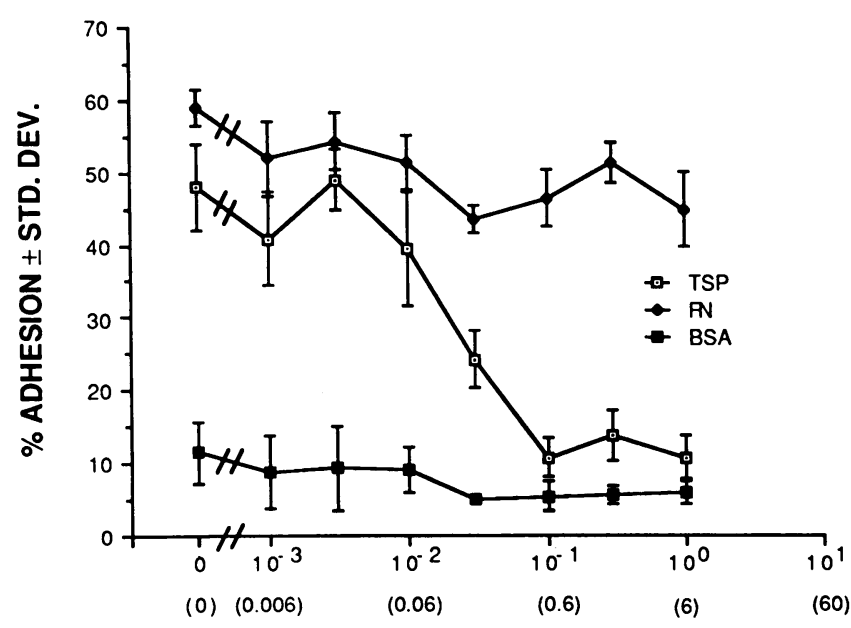

HEPARIN, units $/ \mathrm{ml}(\mu \mathrm{g} / \mathrm{ml})$

Figure 5. Heparin inhibition of CHO K1 cell adhesion to TSP.

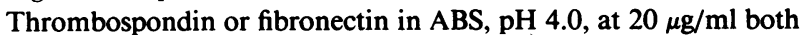
were adsorbed to 96 well tissue culture plates followed by $3.5 \%$ BSA. CHO K1 cells were prepared and labeled, and incubated on protein coated wells as in Fig. 2. Wells had the indicated concentrations of heparin added along with the cells. Bound cells were lysed with $1 \mathrm{~N}$ $\mathrm{NaOH}$, collected and counted. Data shown are the mean percent adhesion of four wells per experimental group \pm SD.

coated wells at 15,75 , and 100 min after the second trypsinization, and adhesion was tested at $105 \mathrm{~min}$ after this trypsinization. Therefore the incubation times of the cells on the protein coated wells were 90,30 , and $5 \mathrm{~min}$, but all cells had 105 min to recover from trypsin. Fig. 6 shows that the second trypsinization significantly inhibited cells adhesion to thrombospondin.

Table II. Activity and Effects of Inhibitors and TSP Fragments

\begin{tabular}{|c|c|c|c|}
\hline \multicolumn{2}{|l|}{ Experiment 1} & \multicolumn{2}{|l|}{ Experiment 2} \\
\hline Inhibitor & Adhesion & TSP fragment & Adhesion \\
\hline & $\%$ & & $\%$ \\
\hline Adsorbed TSP & 83.8 & Adsorbed TSP & 59.0 \\
\hline $\begin{array}{l}\text { Adsorbed } 66 \mathrm{kD} \text { core } \\
+64 \mathrm{kD} \text { carboxy } \\
\text { terminal fragments }\end{array}$ & $<5$ & $\begin{array}{l}\text { Adsorbed TSP plus } \\
\text { dermatan sulfate, } 10 \\
\mu \mathrm{g} / \mathrm{ml}\end{array}$ & 24.5 \\
\hline $\begin{array}{l}\text { Adsorbed } 30 \mathrm{kD} \text { heparin } \\
\text { binding domain }\end{array}$ & 13.7 & $\begin{array}{l}\text { Adsorbed TSP plus } \\
\text { chondroitin sulfate, }\end{array}$ & 54.0 \\
\hline \multirow[t]{3}{*}{$\begin{array}{l}\text { Adsorbed TSP plus soluble } \\
\text { heparin binding domain } \\
\text { at } 40 \mu \mathrm{g} / \mathrm{ml}\end{array}$} & 44.5 & $\begin{array}{l}10 \mu \mathrm{g} / \mathrm{ml} \\
\text { Adsorbed TSP plus } \\
\text { MAb } 2.5,10 \mu \mathrm{g} / \mathrm{ml}\end{array}$ & 40.4 \\
\hline & & $\begin{array}{l}\text { Adsorbed TSP plus } \\
\text { MAb 3.4.2, } 10 \mu \mathrm{g} / \mathrm{ml}\end{array}$ & 73.4 \\
\hline & & $\begin{array}{l}\text { Adsorbed TSP plus } \\
\text { MAb } 3.4 .2,25 \mu \mathrm{g} / \mathrm{ml}\end{array}$ & 80.7 \\
\hline
\end{tabular}

Trypsin digestion of thrombospondin was performed to yield either a mixture of $66 \mathrm{kD}$ core fragment plus COOH-terminal domain, or purified $30 \mathrm{kD}$ heparin binding domain. The cleavage fragments were adsorbed to tissue culture plastic at $20 \mu \mathrm{g} / \mathrm{ml}$, in the presence of $0.5 \mathrm{mM} \mathrm{CaCl}_{2}$, and ${ }^{51} \mathrm{Cr}$-labeled $\mathrm{CHO}$ $\mathrm{K} 1$ cells were tested for adhesion as in Fig. 2. The results are expressed as percent cells bound. In a similar manner, potential inhibitors of adhesion by adsorbing intact TSP at $20 \mu \mathrm{g} / \mathrm{ml}$ to tissue culture plastic and testing CHO KI cell adhesion to the TSP in the presence of these inhibitors.

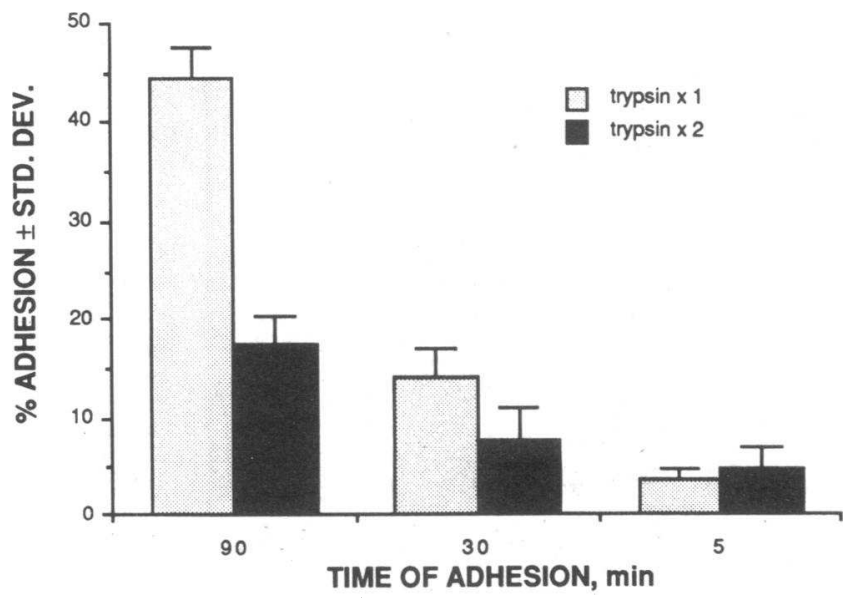

Figure 6. Effect of trypsin on cell adhesion to TSP. TSP in ABS, pH 4.0 , at $20 \mu \mathrm{g} / \mathrm{ml}$ was adsorbed to plastic tissue culture well as in Fig. 2. CHO cells were released from monolayer culture with $0.25 \%$ trypsin, washed, and labeled as in Fig. 2. The cells were divided into two portions after completion of the centrifugation steps of the chromium labeling. One portion was treated with $0.25 \%$ trypsin for 3 min followed by inhibition of trypsin by FCS: these are called "tryp$\sin \times 2$ " cells. The other portion was left untreated for the same time period, and are called "trypsin $\times 1$ " cells. Cells were added to the wells 15,75 , and 100 min after the second trypsin treatment, and adhesion assessed at $105 \mathrm{~min}$ after second trypsin treatment. Data shown is the mean percent adhesion of four wells per experimental group \pm SD.

CHO cell adhesion to thrombospondin cleavage fragment. CHO K1 and S745 cells were tested for adhesion to thrombospondin at $20 \mu \mathrm{g} / \mathrm{ml}$ and to the thrombospondin cleavage fragments minus heparin binding domains at the same molar concentration, both prepared at $\mathrm{pH} 4.0$ in ABS. Table II shows that whereas $84 \%$ of $\mathrm{CHO} \mathrm{K} 1$ cells adhered to intact thrombospondin, less than $5 \%$ adhered to the cleavage fragments. $\mathrm{CHO}$ $\mathrm{K} 1$ cells showed $13.7 \%$ adhesion to purified TSP heparin binding domain, a value not substantially different than for control adhesion to BSA. Purified heparin binding domain, however, inhibited CHO K1 adhesion to intact TSP by about $45 \%$.

Monoclonal antibody A2.5, directed against the heparin binding domain of TSP (39), inhibited CHO K1 cell adhesion by about $33 \%$ at $10 \mu \mathrm{g} / \mathrm{ml}$, while monoclonal antibody 3.4 .2 , directed against the core fragment of TSP, did not inhibit, and perhaps enhanced, adhesion (Table II).

\section{Discussion}

Role of proteoglycans and other molecules in thrombospondin adhesion. We have explored the role of cell surface proteoglycans in cell adhesion to thrombospondin and the relationship of adhesion to binding and degradation of thrombospondin. We found that mutant $\mathrm{CHO}$ cell lines with decreased cell surface proteoglycans showed decreased cell adhesion to thrombospondin compared to the wild type cells, correlating with amounts of cell surface heparan sulfate and chondroitin sulfate proteoglycan. Heparin inhibited $\mathrm{CHO}$ cell adhesion to thrombospondin at concentrations that also inhibited binding and degradation (19). Structure-function relationships with inhibitors were tested with dermatan sulfate and chondroitin sulfate 
as inhibitors. Dermatan sulfate, which has $\sim 50 \%$ of the sulfation, and $50 \%$ of the iduronic acid groups compared to heparin (40), caused inhibition to a lesser degree than did heparin. Chondroitin sulfate, which is poorly sulfated compared to heparin, and does not contain iduronic acid (40), caused no significant inhibition. The order of potency with which heparin, dermatan sulfate and chondroitin sulfate inhibited adhesion correlates with their ability to interact with thrombospondin (41). Most likely the degree of sulfation is the important factor in inhibitory function, however it is possible that iduronic acid content is also important. We found that the parent $\mathrm{CHO}$ line did not adhere to cleavage fragments of thrombospondin that were missing the heparin binding domain, but also did not adhere to purified thrombospondin heparin binding domain. The heparin binding domain did inhibit adhesion of cells to intact thrombospondin, as did a monoclonal antibody to the heparin binding domain of thrombospondin. These data all suggest that cell surface proteoglycan is required for cell adhesion to thrombospondin. Heparan sulfate proteoglycan is most important but cells with excessive chondroitin sulfate proteoglycan can compensate partially for this lack. Heparin is very similar in structure to heparan sulfate, so that inhibition is likely due to a direct interference with the interaction between heparan sulfate chains and thrombospondin.

LeBaron et al. (42) used these same CHO cell lines to study cell adhesion to the heparin binding domain of fibronectin. The wild type $\mathrm{K} 1$ cells and the mutant $\mathrm{S} 745$ cells adhered to intact fibronectin but only the $\mathrm{K} 1$ cells formed F-actin containing stress fibers and focal adhesion plaques. The $\mathrm{K} 1$ cells adhered to the purified heparin binding fragment of fibronectin, however the $\mathbf{S 7 4 5}$ cells did not. These results suggest that proteoglycans are necessary for transmembrane linking of cytoskeletal components to the extracellular matrix.

CHO cells did not spread on thrombospondin while the others (MG-63, G361, and C32) both adhered and spread. This suggests that a second molecule is present on some cells that mediates interaction with thrombospondin. Heparin inhibited MG-63 cell adhesion (our results) and G361 cell spreading (11) to thrombospondin, suggesting that thrombospondin-proteoglycan interactions are important even when other molecules are operative.

Asch et al. showed that the OKM5 antibody, which binds to an $88-\mathrm{kD}$ glycoprotein on platelets (platelet glycoprotein IV) and also binds to monocytes and macrophages, inhibits adhesion of $\mathrm{C} 32$ cells to thrombospondin (18). Using affinity chromatography with the OKM5 antibody, they isolated an 88-kD glycoprotein from the surface of C32 cells with properties consistent with platelet GP IV. They showed that this protein binds thrombospondin and suggested that it may act as a cell surface thrombospondin receptor. G361 cells do not bind the OKM5 antibody and adhesion of G361 cells to thrombospondin is not inhibited by OKM5 (11). Thus, at least three potential thrombospondin receptors (heparan sulfate proteoglycan, GP IV and another receptor present on G361 cells) exist. The third receptor could be a member of the integrin family of cell surface molecules $(43,44)$, inasmuch as thrombospondin has the Arg-Gly-Asp consensus sequence of integrin ligands (45). In CHO cells, these other molecules may not be present or may not recognize their complementary sites on adsorbed thrombospondin.

Role of thrombospondin conformation in adhesion. Cell interactions with thrombospondin are likely to be dependent on the conformational state of the thrombospondin. The $\mathrm{pH}$ at which thrombospondin was adsorbed was important in determining its adhesive characteristics. Thrombospondin adsorbed at pH 4.0 supported adhesion and spreading substantially better than thrombospondin adsorbed at pH 7.4. An important cell adhesion domain therefore, may be preferentially exposed in thrombospondin adsorbed at $\mathrm{pH} 4.0$, perhaps the heparin binding segment. Roberts et al. showed that G361 cells adhere and spread on thrombospondin adsorbed at 50 $\mu \mathrm{g} / \mathrm{ml}$ on bacteriological plastic at $\mathrm{pH} 7.2$ (11). Under these conditions, they found that $\mathrm{C} 32$ cells adhere but do not spread. We found that $\mathrm{C} 32$ cells adhere and spread on thrombospondin adsorbed to tissue culture plastic at pH 4.0. Other investigators have reported that various cell lines adhere to adsorbed thrombospondin. Varani et al. reported the adherence of a squamous cell carcinoma line to thrombospondin adsorbed to tissue culture plastic at pH 6.8 (12). Tuszynski et al. reported the adherence of several cells lines to thrombospondin adsorbed at $40 \mu \mathrm{g} / \mathrm{ml}$ to glass at $\mathrm{pH} 5.5$ (13). Calcium induces a substantial conformational change in thrombospondin (2). Our findings that high calcium concentrations at adsorption enhance adhesion at $\mathrm{pH} 7.4$ but not at $\mathrm{pH} 4.0$ may be due to the small increase in amount of thrombospondin adsorbed at higher calcium but given the small differences in adhesion with large differences in concentration of adsorbed thrombospondin as seen in Fig. 3, it is more likely to be due to a conformational change that exposed the same adhesion domain as when thrombospondin is adsorbed at low $\mathrm{pH}$. This would account for the lack of synergy between low $\mathrm{pH}$ and high calcium.

Our data show, and Tuszynski et al. have reported, that the cell adhesion receptor for thrombospondin is more susceptible to trypsin than is the fibronectin cell adhesion receptor (13). Rapraeger and Bernfield showed that the core protein of integral cell surface heparan sulfate proteoglycan is cleaved by trypsin at a point close to the lipophilic intramembrane domain (20). Our suggestion that the thrombospondin cell adhesion receptor on $\mathrm{CHO}$ cells is a heparan sulfate proteoglycan is consistent with these two findings. Our studies were performed in the absence of inhibitors of protein synthesis, allowing the cells to regenerate thrombospondin receptor after trypsin treatment.

Potential significance of multiple thrombospondin adhesion receptors. The cell adhesion receptor for fibronectin fits the pattern of an alpha chain-beta chain dimer with a site specific for an Arg-Gly-Asp (RGD) sequence in the integrin molecule (46). This molecule is often referred to as "the" fibronectin receptor. However, recently other cell adhesion receptors and cell adhesion domains have been identified in fibronectin. Several groups have identified cells that attach avidly to the heparin binding domain of fibronectin (47-49). Especially interesting is the finding by Rogers et al. that peripheral nervous system cells adhere more strongly to the RGD site while central nervous system cells adhere more strongly to the heparin binding domain, even though each type of cell has receptors for both domains (49). A second cell adhesion site on fibronectin with an Arg-Glu-Asp-Val (REDV) sequence, similar to the RGD sequence, has been identified that is preferentially used over the RGD site for melanoma cell adhesion (50). It should therefore not be surprising to find several cell adhesion domains on a large, multifunctional protein such as thrombospondin. Several potential consequences of cell adhesion to thrombospondin can be hypothesized, such as platelet-endo- 
thelial cell interactions in hemostasis and thrombosis, chemotaxis, and haptotaxis of cells, growth factor activity, embryogenesis and pathologic processes such as atherosclerosis and tumor metastasis. Thus, different types of cells may need different affinity of adhesion, different timing of adhesion, or different affects on intracellular metabolism or growth by adhesion to thrombospondin, which could be regulated by different cell adhesion receptors. For example, a cell in a developing embryo may interact with thrombospondin simply to migrate to and settle in a specific site, while another type of embryonic cell (or the same cell under different circumstances) may interact with thrombospondin to activate mitotic or differentiating processes. Multiple cell adhesion receptors for thrombospondin may confer flexibility of cell interactions with thrombospondin.

Potential importance of cell adhesion to thrombospondin. Thrombospondin is an essential autocrine growth factor for smooth muscle cells, and is synergistic with epidermal growth factor in stimulating mitogenesis $(51,52)$. This effect of thrombospondin is blocked by heparin. Cellular adhesion to thrombospondin that is present in human tissues may be an early step in the stimulation of growth of certain cells. This effect could be important in the diverse events listed above. Heparin inhibition of cell adhesion to thrombospondin by inhibition of interactions between cell surface proteoglycans, as suggested by our data, may be the mechanism by which heparin exerts antiproliferative effects in vitro and in vivo. Whereas fibronectin appears to be a long-term resident of the extracellular matrix, thrombospondin is apparently always a transient occupant of the matrix $(14,34,36,53)$. Because of the transient nature of matrix thrombospondin, interactions with thrombospondin are probably also of a transient nature. Cells may deposit thrombospondin and bind to it, then metabolize the matrix thrombospondin and lift off at appropriate times. It could be expected that cell adhesion to thrombospondin would be more closely tied to changes in cell activity than adhesion to more permanent matrix molecules, and studies into the role of thrombospondin at times of accelerated cell growth and relocation such as embryogenesis and would healing may prove very fruitful in elucidating basic mechanisms.

Thrombospondin has been shown to be a chemotactic and haptotactic agent, and different domains of the molecule are involved in each activity (54). Chemotaxis is mediated by the heparin binding amino-terminus while haptotaxis is mediated by the carboxy terminus. Cell adhesion to thrombospondin may be necessary for the haptotactic response.

Thrombospondin may be involved in tumor cell metastasis. The intravenous injection of thrombospondin before T241 sarcoma cell injection in mice results in enhanced lung colony formation and decreased clearance of tumor from the lungs (55). There are two potential ways in which thrombospondin may be involved in tumor cell attachment and metastasis. Platelets are important to the metastatic process, perhaps by stabilizing interactions between tumor cells and the endothelial cell basement membrane (56). Thrombospondin may be the platelet molecule involved in that process. Thrombospondin is found in the endothelial extracellular matrix (3). Therefore, cellular adhesion to thrombospondin may be involved directly in the attachment of cells to the endothelial cell basement membrane, even though this does not seem to be the case for platelets (57). Whether the finding of enhanced metastasis induced by co-injection of thrombospondin has a physiologic significance has not been established.

\section{Acknowledgments}

Supported by the American Cancer Society Award IN-35-28-16 to Paul R. Kaesberg, Veteran's Administration Merit Award to William B. Ershler, National Institutes of Health Awards GM-33063 to Jeffery D. Esko and HL-29586 to Deane F. Mosher. This work was done during Paul R. Kaesberg's tenure as a Fellow of the American Cancer Society. We thank W. A. Frazier for the A2.5 antibody.

\section{References}

1. Silverstein, R. L., L. L. K. Leung, and R. L. Nachman. 1986. Thrombospondin: A versatile multifunctional glycoprotein. Arteriosclerosis. 6:245-253.

2. Lawler, J. 1986. The structure and functional properties of thrombospondin. Blood. 67:1197-1209.

3. Mosher, D. F., M. J. Doyle, and E. A. Jaffe. 1982. Synthesis and secretion thrombospondin by cultured endothelial cells. J. Cell Biol. 93:343-348.

4. McPherson, J., H. Sage, and P. Bornstein. 1981. Isolation and characterization of a glycoprotein secreted by aortic endothelial cells in culture: apparent identity with platelet thrombospondin. J. Biol. Chem. 256:11330-11336.

5. Kramer, R. H., G. M. Fuh, K. G. Bensch, and M. R. Karasek. 1985. Synthesis of extracellular matrix glycoproteins by cultured microvascular endothelial cells isolated from the dermis of neonatal and adult skin. J. Cell Physiol. 123:1-9.

6. Raugi, G. J., S. M. Mumby, D. Abbott-Brown, and P. Bornstein. 1982. Thrombospondin: Synthesis and secretion by cells in culture. $J$. Cell Biol. 95:351-354.

7. Jaffe, E. A., J. J. Ruggiero, L. L. K. Leung, M. J. Doyle, P. J. McKeown-Longo, and D. F. Mosher. 1983. Cultured human fibroblasts synthesize and secrete thrombospondin and incorporate it into the extracellular matrix. Proc. Natl. Acad. Sci. USA. 80:998-1002.

8. Leung, L. L. K. 1984. Role of thrombospondin in platelet aggregation. J. Clin. Invest. 74:1764-1772.

9. Leung, L. L. K., and R. L. Nachman. 1982. Complex formation of platelet thrombospondin with fibrinogen. J. Clin. Invest. 70:542549.

10. Dixit, V. M., D. M. Haverstack, K. M. O’Rourke, S. W. Hennesey, G. A. Grant, S. A. Santoso, and W. A. Frazier. 1985. A monoclonal antibody against human thrombospondin inhibits platelet aggregation. Proc. Natl. Acad. Sci. USA. 82:3472-3476.

11. Roberts, D. D., J. A. Sherwood, and V. Ginsburg. 1987. Platelet thrombospondin mediates attachment and spreading of human melanoma cells. J. Cell Biol. 104:131-139.

12. Varani, J., V. M. Dixit, S. E. G. Fligiel, P. E. McKeever, and T. E. Carey. 1986. Thrombospondin-induced attachment and spreading of human squamous carcinoma cells. Exp. Cell Res. 167:376-390.

13. Tuszynski, G. P., V. Rothman, A. Murphy, K. Siegler, L. Smith, S. Smith, J. Karczewski, and K. A. Knudsen. 1987. Thrombospondin promotes cell-substratum adhesion. Science (Wash. DC). 236:1570-1573.

14. McKeown-Longo, P. J., R. Hanning, and D. F. Mosher. 1985. Binding and degradation of platelet thrombospondin by cultured fibroblasts. J. Cell Biol. 98:22-28.

15. Silverstein, R. L., and R. L. Nachman. 1987. Thrombospondin binds to monocytes-macrophages and mediates platelet-monocyte adhesion. J. Clin. Invest. 79:867-874.

16. Silverstein, R. L., A. S. Asch, and R. L. Nachman. 1988. The interaction of stimulated platelets with monocytes is mediated by glycoprotein IV. Clin. Res. 36:419a. (Abstr.)

17. Roberts, D. D., D. M. Haverstein, V. M. Dixit, W. A. Frazier, S. A. Santoro, and V. Ginsburg. 1985. The platelet glycoprotein thrombospondin binds specifically to sulfated glycolipids. J. Biol. Chem. 260:9405-9411.

18. Asch, A. S., J. Barnwell, R. L. Silverstein, and R. L. Nachman. 1987. Isolation of the thrombospondin membrane receptor. J. Clin. Invest. 79:1054-1061. 
19. Murphy-Ullrich, J. E., and D. F. Mosher. 1987. Interactions of thrombospondin with endothelial cells: receptor-mediated binding and degradation. J. Cell Biol. 105:1603-1611.

20. Rapraeger, A., and M. Bernfield. 1985. Cell surface proteoglycan of mammary epithelial cells. Protease releases a heparan sulfaterich ectodomain from a putative membrane-anchored domain. J. Biol. Chem. 260:4103-4109.

21. Kjellan, L., A. Oldberg, and M. Hook. 1980. Cell surface heparan sulfate. Mechanism of proteoglycan-cell association. J. Biol. Chem. 255:10407-10413.

22. Rapraeger, A., J. E. Koda, and M. Bernfield. 1987. Matrix interactions of cell surface proteoglycans. In Connective Tissue Disease: Molecular Pathology of the Extracellular Matrix. J. Uitto and A. J. Perejda, editors. Marcel Dekker, Inc., New York. 213-232.

23. Yamada, K. M., D. W. Kennedy, K. Kimata, and R. M. Pratt. 1980. Characterization of fibronectin interactions with glycosaminoglycans and identification of active proteolytic fragments. J. Biol. Chem. 255:6055-6063.

24. Ruoslahti, E., and E. Engvall. 1980. Complexing of fibronectin, glycosaminoglycans and collagen. Biochim. Biophys. Acta. 631:350358.

25. Stamatoglou, S. C., and J. M. Keller. 1982. Interactions of cellular glycosaminoglycans with plasma fibronectin and collagen. Biochim. Biophys. Acta. 719:90-97.

26. Isemura, M., N. Sato, Y. Yamaguchi, J. Aikawa, H. Munakata, N. Hayceski, Z. Yosizawa, T. Nakamura, A. Kubota, M. Arakawa, and C. C. Hsu. 1987. Isolation and characterization of fibronectin-binding proteoglycan carrying both heparan sulfate and dermatan sulfate chains from human placenta. J. Biol. Chem. 262:8926-8933.

27. Woodley, D. T., C. N. Rao, J. R. Hassel, L. A. Liotta, G. R. Martin, and H. Kleinman. 1983. Interactions of basement membrane components. Biochim. Biophys. Acta. 761:278-283.

28. Stamatoglou, S., and J. Keller. 1983. Correlation between cell substrate attachment in vitro and cell surface heparan sulfate affinity for fibronectin and collagen. J. Cell Biol. 96:1820-1823.

29. Koda, J. E., and M. Bernfield. 1984. Heparan sulfate proteoglycans from mouse mammary epithelial cells. Basal extracellular proteoglycan binds specifically to native type I collagen fibrils. J. Biol. Chem. 259:11763-11770.

30. Koda, J. E., A. Rapraeger, and M. Bernfield. 1985. Heparan sulfate proteoglycans from mouse mammary epithelial cells. Cell surface proteoglycan as a receptor for interstitial collagens. J. Biol. Chem. 260:8157-8162.

31. Esko, J. D., T. E. Stewart, and W. H. Taylor. 1985. Animal cell mutants defective in glycosaminoglycan biosynthesis. Proc. Natl. Acad. Sci. USA. 82:3197-3201.

32. Esko, J. D., A. Elgaish, T. Prasthofer, W. H. Taylor, and J. L. Weinke. 1986. Sulfate transport-deficient mutants of chinese hamster ovary cells. Sulfation of glycosaminoglycans dependent on cysteine. $J$. Biol. Chem. 261:15725-15733.

33. Esko, J. D., J. L. Weinke, W. H. Taylor, G. Ekborg, L. Roden, G. Anantharamaiah, and A. Gawish. 1987. Inhibition of chondroitin and heparan sulfate biosynthesis in chinese hamster ovary cell mutants defective in galactosyltransferase I. J. Biol. Chem. 262:12189-12195.

34. Murphy-Ullrich, J. E., L. G. Westrick, J. D. Esko, and D. F. Mosher. 1988. Altered metabolism of thrombospondin by chinese hamster ovary cells defective in glycosaminoglycan synthesis. J. Biol. Chem. 263:6400-6406.

35. Akers, R. M., D. F. Mosher, and J. E. Lilien. 1981. Promotion of retinal neurite outgrowth by substratum-bound fibronectin. Devel. Biol. 86:179-188.

36. Murphy-Ullrich, J. E., and D. F. Mosher. 1985. Localization of thrombospondin in clots formed in situ. Blood. 66:1098-1104.

37. Bale, M. D., L. G. Westrick, and D. F. Mosher. 1985. Incorporation of thrombospondin into fibrin clots. J. Biol. Chem. 260:75027508.

38. Mosher, D. F., and R. B. Johnson. 1983. In vitro formation of disulfide-bonded fibronectin multimers. J. Biol. Chem. 258:65956601 .

39. Galvin, N. J., V. M. Dixit, K. M. O'Rourke, S. A. Santoro, G. A. Grant, and W. A. Frazier. 1985. Mapping of epitopes for monoclonal antibodies against human platelet thrombospondin with electron microscopy and high sensitivity amino acid sequencing. J. Cell Biol. 101:1434-1441.

40. Lindahl, U., and M. Hook. 1978. Glycosaminoglycans and their binding to biological macromolecules. Annu. Rev. Biochem. 47:385-418.

41. Slayter, H. S., G. Karp, B. E. Miller, and R. D. Rosenberg. 1987. Binding properties of human thrombospondin: Interaction with mucopolysaccharides. Semin. Thromb. Hemostasis. 13:369-377.

42. LeBaron, R. G., J. D. Esko, A. Woods, S. Johansson, and M. Hook. 1988. Adhesion of glycosaminoglycan-deficient chinese hamster ovary cell mutants to fibronectin substrata. J. Cell Biol. 106:945952.

43. Pytela, R., M. D. Pierschbacher, and E. Ruoslahti. 1985. Identification and isolation of a $140 \mathrm{kD}$ cell surface glycoprotein with properties expected of a fibronectin receptor. Cell. 40:191-198.

44. Hynes, R. O. 1987. Integrins: A family of cell surface receptors. Cell. 48:549-554.

45. Lawler, J., and R. O. Hynes. 1986. The structure of human thrombospondin, an adhesive glycoprotein with multiple calcium binding sites and homologies with several different proteins. J. Cell Biol. 103:1635-1648.

46. Pytela, R., M. D. Pierschbacher, M. HI. Ginsberg, E. F. Plow, and E. Ruoslahti. 1986. Platelet membrane glycoprotein IIb/IIIa: a member of a family of Arg-Gly-Asp-specific adhesion receptors. Science (Wash. DC). 231:1559-1562.

47. Izzard, C. S., R. Radinsky, and L. A. Culp. 1986. Substratum contacts and cytoskeletal reorganization of BALB/c 3T3 cells on a cell-binding fragment and heparin binding fragments of plasma fibronectin. Exp. Cell Res. 165:320-326.

48. Woods, A., M. Hook, L. Kjellen, C. G. Smith, and D. A. Rees. 1984. Relationship of heparan sulfate proteoglycans to the cytoskeleton and extracellular matrix of cultured fibroblasts. J. Cell Biol. 99:1743-1753.

49. Rogers, S. L., P. C. Letourneau, B. A. Peterson, L. T. Furcht, and J. B. McCarthy. 1987. Selective interaction of peripheral and central nervous system cells with two distinct cell-binding domains of fibronectin. J. Cell Biol. 105:1435-1447.

50. Humphries, M. J., S. K. Akiyama, A. Komoriya, K. Olden, and K. M. Yamada. 1986. Identification of an alternatively spliced site in human plasma fibronectin that mediates cell type-specific adhesion. $J$. Cell Biol. 103:2637-2647.

51. Majack, R. A., S. C. Cook, and P. Bornstein. 1986. Control of smooth muscle growth by components of the extracellular matrix: Autocrine role for thrombospondin. Proc. Natl. Acad. Sci. USA. 83:9050-9054.

52. Majack, R. A., L. V. Goodman, and V. M. Dixit. 1988. Cell surface thrombospondin is functionally essential for vascular smooth muscle cell proliferation. J. Cell Biol. 106:415-422.

53. Raugi, G. J., J. E. Olerud, and A. M. Gown. 1987. Thrombospondin in early human wound tissue. J. Invest. Dermatol. 89:551554.

54. Taraboletti, G., D. D. Roberts, and L. A. Liotta. 1987. Thrombospondin-induced tumor cell migration: Haptotaxis and chemotaxis are mediated by different molecular domains. J. Cell Biol. 105:24092415.

55. Tuszynski, G. P., T. B. Gasic, V. L. Rothman, K. A. Knudsen, and G. J. Gasic. 1987. Thrombospondin, a potentiator of tumor cell metastasis. Cancer Res. 47:4130-4133.

56. Mehta, P. 1984. Potential role of platelets in the pathogenesis of tumor metastasis. Blood. 63:55-63.

57. Houdijk, W. P. M., P. G. deGroot, P. F. E. M. Nievelstein, K. S. Sakariassen, and J. J. Sixma. 1986. Subendothelial proteins and platelet adhesion. Arteriosclerosis. 6:24-33. 